\title{
Musculoskeletal system pain and related factors in mothers of children with cerebral palsy
}

\author{
Serebral palsili çocuğa sahip annelerde musküloskeletal sistem ağrıları ve \\ ilişkili faktörler
}

Rabia TERZi,' ' Gülten TAN²

\begin{abstract}
Summary
Objectives: The aim of the present study was to identify prevalence of musculoskeletal system diseases and related factors among mothers of children with cerebral palsy.

Methods: Eighty-five mothers of children with cerebral palsy were included as the treatment group, and 42 mothers of healthy children were included as the control group. Sociodemographic characteristics of all subjects were recorded. Musculoskeletal system pain was evaluated by the standardized Nordic Musculoskeletal Questionnaire, and level of depression was evaluated according to Beck's Depression Scale.

Results: Musculoskeletal system pain and depression scores of the treatment group were significantly higher than those of the control group. Most frequently reported by mothers in the treatment group was low back pain (44.7\%). In multiple regression analysis, number of children, age, and functional level of the child with cerebral palsy, as well as depression level of the mother were identified as independent risk factors for musculoskeletal system pain.

Conclusion: Mothers of children with cerebral palsy are at higher risk for musculoskeletal system pain and depression. Prevalence of musculoskeletal system pain in these mothers, especially those with older children who have lower functional statuses, should be kept in mind.
\end{abstract}

Keywords: Cerebral palsy; children; mothers; pain.

\section{Özet}

Amaç: Amacımız serebral palsili çocuğa sahip olan annelerde görülen musküloiskeletal sistem ağrıları ve bunlarla ilişkili faktörlerin belirlenebilmesidir.

Gereç ve Yöntem: Çalışmamıza serebral palsili çocuğa sahip 85 kadın ile, kontrol grubu sağlıkı çocuğa sahip 42 kadın dahil edilmiştir. Tüm annelerin sosyodemografik özellikleri kaydedilmiştir. Kas iskelet sistem ağrıları standardize edilmiş İskandinav Kas-İskelet Sistemi Anketi ile, depresyon düzeyleri Beck depresyon skalasına göre değerlendirilmiştir.

Bulgular: Serebral palsili çocuğa sahip annelerde kas iskelet sistem ağrıları ve depresyon skorları, kontrol grubuna göre istatistiksel olarak anlamlı oranda yüksek bulunmuştur. Serebral palsili çocuğa sahip annelerde en sık görülen ağrı bel ağrısıydı (\%44.7). Yapılan multipl regresyon analizinde serebral palsili çocuğa sahip annelerde kas iskelet sistemi ağrılarında; çocuk sayısı, serebral palsili çocuğun yaşı, çocuğun fonksiyonel düzeyi ve anne depresyon düzeyi bağımsız risk faktörleri olarak bulunmuştur.

Sonuç: Serebral palsili çocuğa sahip anneler sağlıklı çocuklara sahip annelere göre kas iskelet sistem ağrıları ve depresif bulgular açııından risk altındadırlar. Özellikle fonksiyonel düzeyi kötü, yaşca büyük serebral palsili çocuğa sahip annelerde kas iskelet sistemine ait ağrılarının daha sık gözlendiği unutulmamalıdır.

Anahtar sözcükler: Serebral palsi; çocuklar; anneler; ağrı.

'Department of Physical Medicine and Rehabilitation, Derince Training and Research Hospital, Kocaeli, Turkey ${ }^{2}$ Department of Physical Medicine and Rehabilitation, Izmir University Faculty of Medicine Hospital, Izmir, Turkey

Correspondence: Dr. Rabia Terzi. Derince Eğitim ve Araştırma Hastanesi, Fiziksel Tıp ve Rehabilitasyon Kliniği, Kocaeli, Turkey. 


\section{Introduction}

Cerebral palsy is a neurodevelopmental disorder accompanied by motor developmental disability, and cognitive, sensorial and communicative impairments which develops as a result of the response of the immature brain due to various causes. ${ }^{[1]}$ There is a need for long-term care and support, particularly for the mothers of the children with cerebral palsy as well as the families. ${ }^{[2]}$ To have a child with a disability brings about some specific difficulties. The increased dependence on the mother could negatively affect the future expectations, emotional status ${ }^{[3]}$ and life quality ${ }^{[4]}$ of the mother.

The mothers who have children with CP provide active support to their children in terms of personal care, transfer, daily life activities and treatment ${ }^{[5]}$ during which they may be exposed to physical trauma and heavy loads. It is known that chronic physical loading could produce problems in the musculoskeletal system ${ }^{[6]}$ There are a limited number of studies in the literature evaluating musculoskeletal system pain and the related factors that are observed in the mothers of the children with cerebral palsy. ${ }^{[7]}$ Knowing the extent and the risk factors of the problems in the musculoskeletal system of these mothers is of importance to determine the support and the approach to be provided to this group. It is also important for the quality of the care and the rehabilitation support that is provided to the healthy children of these mothers. The aim of the current study was to determine musculoskeletal system pain and the related factors observed in the mothers of children diagnosed with cerebral palsy.

\section{Materials and Methods}

Eighty-five females who had children with cerebral palsy (CP) were included in the study as the treatment group and 42 females who had healthy children that were similar in age and demographics were included in the study as the control group. All participants were informed about the study, the assessments were conducted via the face-to-face contact. The ethical committee approval was obtained.

The mothers aged between 18-45, who lived with their children and their partners, were included in the study. Exclusion criteria were as follows: mothers who had a history of musculoskeletal disease before having a child; those who had undergone locomotor system surgery; those who had a history of rheumatic or psychological diseases; those had active infection or severe systemic disease; mothers who were not responsible for the primary care of the child or who had an assistant caregiver; mothers who had an active occupational life; and mothers who had more than one disabled child.

Sociodemographic data of the participants (age, height, weight and income and education levels) and the number of children were included in the questionnaire. The Standardized Scandinavian Musculoskeletal System Questionnaire (The Nordic Musculoskeletal Questionnaire-NMQ) was used ${ }^{[8]}$ for the evaluation of musculoskeletal system pain within the last one year. Complaints of pain developing in nine regions of the body (feet-ankles, knees, thighhip, wrist-hands, waist, elbows, back region, shoulders and neck) were questioned and marked by mapping and the presence of the pain was recorded. The participants were asked whether the pain that had developed within the last year prevented them from doing normal work (at home or outside home) or whether hospitalization was required due to this pain. ${ }^{[9]}$ The participants who responded "Yes" to the first two questions as were accepted as having pain related to the musculoskeletal system.

The depression level of the participants was evaluated according to Beck's Depression Scale. Beck's depression scale is a scale that consists of 21 questions and in which the answers are evaluated with scores between 0 and 3. A high score indicates the severity of the depression. ${ }^{[10]}$ Previously formed questions related to the disease of the children were asked to the mothers who had children with cerebral palsy. The demographic characteristics of the children (age, height and weight) were recorded. The functional statuses were questioned according to the Gross Motor Function Classification System (GMFCS) scale. The functional statuses of the children were graded between 1 and 5: Grade 1- walks independently; Grade 2-walks without an assisting device and there are limitations in walking; Grade 3-walks with an assisting device and there are limitations while walking in public; Grade 4-self-movements are limited, the child is mobile on his or her own, moves with an assisting device and is transported in the public 
or uses wheelchair; Grade 5-mobilization is severely limited although uses assisting technologies. ${ }^{[11,12]}$

\section{Statistical Analyses}

Number Cruncher Statistical System (NCSS) 2007 and Power Analysis and Sample Size (PASS) 2008 Statistical Software (Utah, USA) programs were used for the statistical analysis. While evaluating the study data, in addition to the definitive statistical methods (mean, standard deviation, median, frequency, ratio, minimum and maximum), in the comparison of the quantitative data, Student's $t$ test was used in the two group comparisons of the parameters that have normal distribution and Mann Whitney $U$ test was used in the two-group comparisons of the parameters without normal distribution. Pearson's chi-square test and Fisher's exact test were used in the comparison of the qualitative data. Spearman's correlation analysis was used in the evaluation of the correlation between the parameters. Stepwise logistical regression was used for the multivariate analysis. Values of $p<0.01$ and $p<0.05$ were deemed statistically significant.

\section{Results}

The study was performed on eighty-five females who had children with cerebral palsy and 42 females who had a healthy child or children as the control group. The age of the participants ranged between 24 and 45 years and the mean age was $34.77 \pm 6.61$ years. No statistically significant difference was found between two groups in terms of the sociodemographic characteristics and the number of patients $(p>0.05)$. While the Beck scores in the mothers who had children with cerebral palsy was $18.41 \pm 11.19$, it was $9.21 \pm 4.26$ in the control group. This difference was statistically significant $(p=0.001 ; p<0.01)$ rehabilitation (Table 1$)$.

The mean age of the children with cerebral palsy was $7.95 \pm 5.45$ years, the mean height was $113.82 \pm 25.71$, the mean weight was $24.19 \pm 16.02$, and the mean score of coarse motor function was $3.49 \pm 1.35$. The incidence of neck pain and back and low back pain within the last one year was significantly higher in the mothers who had children with cerebral palsy when compared to the same values in the control group ( $p=0.003 ; p=0.001$, and $p=0001$, respectively). The incidence of musculoskeletal system pain in any region of the body within the last one year in the mothers of children with cerebral palsy was significantly higher than the mothers who did not have children with cerebral palsy ( $p=0.001 ; p<0.01$ ) (Table 2 ).

It was found that the age of the mothers who had children with cerebral palsy and who experienced pain within the last one year was significantly older than the mothers who did not experience pain. Moreover, these mothers' (i.e. the ones who experienced pain within the last one year) number of children was greater, Beck depression scores were higher and the age and height of the children were

Table 1. Assessment related to the definitive characteristics of the mothers

\begin{tabular}{|c|c|c|c|c|c|c|c|c|c|c|}
\hline \multirow[t]{2}{*}{ Characteristics of the mothers } & \multicolumn{3}{|c|}{ Total } & \multicolumn{3}{|c|}{$C P(+)(n=85)$} & \multicolumn{3}{|c|}{$C P(-)(n=43)$} & \multirow[t]{2}{*}{$\mathbf{p}$} \\
\hline & $\mathbf{n}$ & $\%$ & Mean \pm SD & $\mathbf{n}$ & $\%$ & Mean \pm SD & $\mathbf{n}$ & $\%$ & Mean \pm SD & \\
\hline Age (year) & & & $34.77 \pm 6.61$ & & & $34.75 \pm 6.70$ & & & $34.81 \pm 6.52$ & a 0.961 \\
\hline Height (cm) & & & $160.84 \pm 4.69$ & & & $160.89 \pm 4.81$ & & & $160.72 \pm 4.50$ & a 0.844 \\
\hline Weight (kg) & & & $68.95 \pm 9.85$ & & & $68.26 \pm 10.02$ & & & $70.30 \pm 9.51$ & ${ }^{\mathrm{a}} 0.270$ \\
\hline Number of children (median) & & & $1.95 \pm 0.92(2)$ & & & $1.93 \pm 1.01(2)$ & & & $1.98 \pm 0.71(2)$ & b0.306 \\
\hline Beck score (median) & & & $15.32 \pm 10.39$ & & & $18.41 \pm 11.19$ & & & $9.21 \pm 4.26$ & ${ }^{b} 0.001^{* *}$ \\
\hline \multicolumn{11}{|l|}{ Educational status } \\
\hline Primary school & 93 & 72.7 & & 62 & 72.9 & & 31 & 72.1 & & 0.919 \\
\hline High school, university & 35 & 27.3 & & 23 & 27.1 & & 12 & 27.9 & & \\
\hline \multicolumn{11}{|l|}{ Income status } \\
\hline Low & 49 & 38.3 & & 29 & 34.1 & & 20 & 46.5 & & '0.173 \\
\hline Medium, good & 79 & 61.7 & & 56 & 65.9 & & 23 & 53.5 & & \\
\hline
\end{tabular}

CP: Cerebral palsy; SD: Standard deviation; ${ }^{a}$ Student's t-test; ${ }^{b}$ Mann Whitney U-test; ${ }^{~}$ Fisher-Freeman-Halton exact test; ${ }^{*} p<0.05 ;{ }^{* *} p<0.01$. 
Table 3. Assessments according to the presence of musculoskeletal system pain within the last one year in mothers who had children with

\begin{tabular}{|c|c|c|c|c|c|c|c|c|c|}
\hline & \multicolumn{4}{|c|}{ Pain $(+)(n=54)$} & \multicolumn{4}{|c|}{ Pain $(-)(n=31)$} & \multirow[t]{2}{*}{$\mathbf{p}$} \\
\hline & $\mathbf{n}$ & $\%$ & Mean \pm SD & Median & $\mathbf{n}$ & $\%$ & Mean \pm SD & Median & \\
\hline Mother's age (year) & & & $36.35 \pm 7.37$ & & & & $31.97 \pm 4.14$ & & ${ }^{\mathrm{a}} 0.001^{* *}$ \\
\hline Mother's height $(\mathrm{cm})$ & & & $160.56 \pm 5.46$ & & & & $161.48 \pm 3.38$ & & ${ }^{\mathrm{a}} 0.336$ \\
\hline Mother's weight (kg) & & & $67.93 \pm 9.75$ & & & & $68.84 \pm 10.61$ & & a 0.689 \\
\hline Number of children & & & $2.13 \pm 1.13$ & 2 & & & $1.58 \pm 0.62$ & 2 & ${ }^{b} 0.028^{*}$ \\
\hline Children's age (year) & & & $9.20 \pm 5.96$ & 8 & & & $5.77 \pm 3.57$ & 5 & b0.009** \\
\hline Children's height $(\mathrm{cm})$ & & & $119.57 \pm 21.81$ & & & & $103.81 \pm 29.12$ & & ${ }^{b} 0.006^{* *}$ \\
\hline Children's weight (kg) & & & $26.57 \pm 18.54$ & 19 & & & $20.05 \pm 9.16$ & 17 & ${ }^{\mathrm{a}} 0.060$ \\
\hline $\begin{array}{l}\text { Coarse motor function } \\
\text { classification system score }\end{array}$ & & & $3.78 \pm 1.37$ & 4 & & & $3.00 \pm 1.18$ & 3 & ${ }^{b} 0.016^{*}$ \\
\hline Beck inventory scale score & & & $23.06 \pm 11.14$ & 22 & & & $10.32 \pm 5.03$ & 9 & ${ }^{b} 0.001^{* *}$ \\
\hline \multicolumn{10}{|l|}{ Mother's education status } \\
\hline Primary school & 44 & 71.0 & & & 18 & 29.0 & & & ${ }^{c} 0.019^{*}$ \\
\hline High school, university & 10 & 43.5 & & & 13 & 56.5 & & & \\
\hline \multicolumn{10}{|l|}{ Income status } \\
\hline Low & 25 & 86.2 & & & 4 & 13.8 & & & ${ }^{c} 0.002^{* *}$ \\
\hline Medium, good & 29 & 51.8 & & & 27 & 48.2 & & & \\
\hline
\end{tabular}

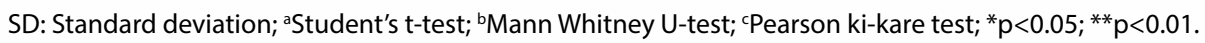

greater $(p<0.05)$ and the weight of the children was prominently greater, however, these differences were not statistically significant.

The coarse motor function values of the children belonging to the mothers, who had children with cerebral palsy and had experienced pain within the last one year, was significantly higher and their (i.e. children's) functional status was bad when compared with the children of the mothers who did not experience pain $(p=0.016 ; p<0.05)$.

The incidence of pain within the last one year was significantly higher in the mothers who had children with cerebral palsy and who had low education and socioeconomic status when compared with the mothers who had high education and socioeconomic levels $(p=0.019 ; p<0.05)(p=0.002 ; p<0.01)$ (Table 3$)$.

When the risk factors affecting musculoskeletal pain within the last one year in the mothers who had children with cerebral palsy, such as mother's age, number of children, age, height of the child, coarse motor assessment score, Beck's depression score, the education status of the mother and the economic status of the family were evaluated with stepwise logistic regression analysis, the model was found to be significant and the descriptive coefficient (81.2\%) was at very good level. At the end of the eighth step, the effects of the factors such as the number of children, the age of the children, coarse motor assessment score, and Beck's score remained as the independent risk factors for the pain within the last one year. The effects of other variables on logistical model were not statistically significant ( $p>0.05$ ) (Table 4).

There was a statistically significant correlation at a level of $58.4 \%$ between the Beck scores of the mothers and the total number of regions in which musculoskeletal system pain developed within the last one year ( $r=0.584 ; p=0.001 ; p<0.01$, respectively). A positive correlation was found between the Beck scores of the mothers who had children with cerebral palsy and the level of coarse motor function of the children with cerebral palsy $(r=0.484 ; p=0.3)$.

\section{Discussion}

In the current study, the incidence of neck pain and back and low back pain within the last one year and 
Table 4. Logistic regression analysis of the risk factors affecting musculoskeletal pain detected within the last one year

\begin{tabular}{lcccc}
\hline & $\mathbf{p}$ & ODDS & \multicolumn{2}{c}{$\mathbf{9 5 . 0 \%} \mathrm{Cl}$} \\
\cline { 4 - 5 } & & & Lower & Upper \\
\hline Number of children & $\mathbf{0 . 0 4 8 ^ { * }}$ & 3.004 & 1.090 & 9.352 \\
Children's age & $\mathbf{0 . 0 2 4}^{*}$ & 1.186 & 1.023 & 1.376 \\
Gross motor function score & $\mathbf{0 . 0 0 1}^{* *}$ & 3.046 & 1.603 & 5.788 \\
Beck depression inventory score & $\mathbf{0 . 0 0 2 ^ { * * }}$ & 1.265 & 1.092 & 1.467 \\
Mother's age & $\mathbf{0 . 8 8 9}$ & 0.986 & 0.812 & 1.198 \\
Children's height & $\mathbf{0 . 4 4 2}$ & 0.979 & 0.927 & 1.034 \\
Education status & $\mathbf{0 . 4 6 8}$ & 1.957 & 0.320 & 11.972 \\
Income status & $\mathbf{0 . 3 2 3}$ & 2.485 & 0.409 & 15.106 \\
\hline
\end{tabular}

${ }^{*} \mathrm{p}<0.05 ;{ }^{* *} \mathrm{p}<0.01$.

the depression scores in the mothers who had children with cerebral palsy were significantly higher than those values in the mothers who had healthy children. The number of children, the age of the child with cerebral palsy, the functional level of the child and the depression level of the child were independent risk factors in the musculoskeletal system pain of the mothers who had children with cerebral palsy and who developed locomotor system pain. Studies in the literature reported that the quality of life was disturbed and the physical health, in particular, was negatively affected. ${ }^{[4,11]}$ As far as we know, there is only one detailed article in the literature related to musculoskeletal problems and the pain that developed in the mothers who had children with cerebral palsy. ${ }^{[7]}$ In this aspect, the results of the current study are valuable.

In the current study, the coarse motor assessment scores were found to be one of the independent variables in musculoskeletal system pain developing in mothers. The study of Prudente et al., in which following a 10-month rehabilitation program, the motor function of the children with cerebral palsy and the life quality of the mothers were investigated, they found an improvement in the coarse motor functions in children following rehabilitation and improvement in only body pain among the lower domains of life quality of the mothers. ${ }^{[13]}$ In the study of Duger et al.. ${ }^{[14]}$ which was performed on mothers who had children with muscular dystrophy, they found a correlation between back pain and daily life activities of the children. The current study also supports the finding that as the functional dependency increases, the complaint of pain also increases in this patient group. As the functional dependency of the child increases, the mother was required to provide more support in the daily activities of the children and thus take on a greater physical load. It was thought that this condition could cause problems related to the musculoskeletal system.

In the present study, the number of children and the age of the child with cerebral palsy were other independent risk factors in musculoskeletal system pain that develops in the mothers who had children with cerebral palsy. Sixty-five to ninety percent of the cases with cerebral palsy live until adult age, ${ }^{[2]}$ therefore, the care provided by the mother who had a child with cerebral palsy is a one-way, dependent and long-term process. ${ }^{[2]}$ The age of the child is important for the duration of this care. As the child grows, the physical load and requirements of the child increase and the parent ages. The present study found that the age of the mothers who suffered from the pain and whose children had CP was older. The studies in the literature have demonstrated that together with the increasing age, pain increases and the tolerance of the pain decreases. ${ }^{[15]}$ The degenerative changes that develop in the joints, together with the increasing age, might render the mothers in this group under the risk for the development of pain.

Some previous studies have reported that the depression and anxiety levels in the mothers who had children with cerebral palsy were higher than those in mothers who had healthy children. ${ }^{[3,16,17]}$ The fac- 
tors that might contribute to high depression scores in these mothers are mainly having a disabled child and the resulting increased responsibilities and consequently the necessity to cope with more problems and stress, giving up professional occupations, because they undertake the care of the children and the consequent worsening in the economic status, the limitations in social activities and sleep disturbances. ${ }^{[3,16-18]}$ It has been demonstrated that the depression levels in these mothers might be related to the type and severity of cerebral palsy. ${ }^{[3]}$ In the current study, the depression levels were higher than the depression levels in the mothers who had children with cerebral palsy and a correlation was found between the depression levels of the mothers and the functional status of the children with cerebral palsy.

Depression and chronic stress might cause physical symptoms related to stress in these mothers. ${ }^{[19]}$ The prolonged stress and depression might affect immunological functions by causing dysfunction and excessive stimulation in the neuroendocrinological stress response system. ${ }^{[20]}$ In a previous study, the cellular age of the mothers who felt high levels of stress because of their physically disabled children, was 9-17 years older than the mothers who had low stress levels and it was found that the stress the mothers feel was correlated with the cellular aging. ${ }^{[21]}$ Previous studies have demonstrated the correlation between the symptoms of depression and the impairment in physical health and chronic pain. ${ }^{[2,22]}$ In the current study, the depression levels were correlated with the musculoskeletal pain that developed within the last one year. The increased musculoskeletal pain in these mothers was thought to be caused by the negative effects of chronic stress and the symptoms of depression on the physical health, in addition to the physical load to which they were exposed.

In the study of Kaya et al., ${ }^{[7]}$ in which musculoskeletal pain was evaluated in 81 mothers who had children with cerebral palsy and in 60 mothers who had healthy children, it was found that musculoskeletal and lumbar pain were more frequently seen in mothers who had children with cerebral palsy and the Beck depression scores in this group were higher. It was mentioned that the low back pain could cause impairment in the quality of life in these patients. In the current study, while the neck, low back, and back pain were found to be significantly higher in the mothers who had children with $\mathrm{CP}$, similarly the most common type of pain was low back pain $(44.7 \%)$ in this group. The study of Tong et al. ${ }^{[9]}$ found the incidence of low back pain was $71.1 \%$ in female caregivers of children with physical disabilities and this ratio was lower in caregivers of the children without physical disabilities. When the factors related to low back pain were evaluated according to the logistic regression model, a correlation was found between the low back pain and the transfer ability of the children. It was thought that the increased requirement for assistance by children with physical disabilities could have increased the rates of low back pain observed in the caregivers of these children. Similarly, in the current study, the scores of the functional status of the children of the mothers who had musculoskeletal pain was lower.

The limitations of the current study include the fact that it is a single centered study, it did not include mothers who had more than one disabled child and working mothers and thus does not reflect the general population in this group. Furthermore, it did not evaluate other factors such as spasticity, joint contracture, mental retardation, auditory, visual and incontinence problems that could cause difficulty in the home care and daily life activities of children with cerebral palsy and might cause a predisposition to musculoskeletal system pain in these mothers. As the current study is a sectional study, in interrogation of the musculoskeletal pain the data was collected subjectively according to the declarations of the mothers, the presence of environmental factors, increasing pain and the type of activities that cause pain development were not included.

In conclusion, it should be kept in mind that many complaints and depressive symptoms could develop in the mothers of the children who were diagnosed with cerebral palsy. It should be considered, and thus the preventive measures should be taken, that musculoskeletal system pain, in particular, is more frequently seen in mothers who had a greater number of children, who had children with cerebral palsy with poor functional status, and those mothers who had much older children with cerebral palsy. There is need for multicenter, detailed, prospective, longitudinal studies in this field. 


\section{Conflict-of-interest issues regarding the authorship or article: None declared.}

\section{Peer-rewiew: Externally peer-reviewed.}

\section{References}

1. Rosenbaum P, Paneth N, Leviton A, Goldstein M, Bax M, Damiano $D$, et al. A report: the definition and classification of cerebral palsy April 2006. Dev Med Child Neurol Suppl 2007;109:8-14.

2. Rapp CE Jr, Torres MM. The adult with cerebral palsy. Arch Fam Med 2000;9(5):466-72.

3. Unsal-Delialioglu S, Kaya K, Ozel S, Gorgulu G. Depression in mothers of children with cerebral palsy and related factors in Turkey: a controlled study. Int J Rehabil Res 2009;32(3):199-204.

4. Eker L, Tüzün EH. An evaluation of quality of life of mothers of children with cerebral palsy. Disabil Rehabil 2004;26(23):1354-9.

5. Aydın R, Nur H. Family-centered approach in the management of children with cerebral palsy. Turk J Phys Med Rehab 2012;58(3):229-35.

6. Picavet HS, Schouten JS. Physical load in daily life and low back problems in the general population-The MORGEN study. Prev Med 2000;31(5):506-12.

7. Kaya K, Unsal-Delialioglu S, Ordu-Gokkaya NK, Ozisler Z, Ergun N, Ozel S, et al. Musculo-skeletal pain, quality of life and depression in mothers of children with cerebral palsy. Disabil Rehabil 2010;32(20):1666-72.

8. Kuorinka I, Jonsson B, Kilbom A, Vinterberg $H$, Biering-Sørensen $F$, Andersson $G$, et al. Standardised Nordic questionnaires for the analysis of musculoskeletal symptoms. Appl Ergon 1987;18(3):233-7.

9. Tong HC, Kandala G, Haig AJ, Nelson VS, Yamakawa KS, Shin KY. Physical functioning in female caregivers of children with physical disabilities compared with female caregivers of children with a chronic medical condition. Arch Pediatr Adolesc Med 2002;156(11):1138-42.

10. Beck AT, Ward $\mathrm{CH}$, Mendelson M, Mock J, Erbaugh J. An inventory for measuring depression. Arch Gen Psychiatry 1961;4:561-71.
11. Palisano R, Rosenbaum P, Walter S, Russell D, Wood E, Galuppi B. Development and reliability of a system to classify gross motor function in children with cerebral palsy. Dev Med Child Neurol 1997;39(4):214-23.

12. Dehghan L, Dalvand H, Feizi A, Samadi SA, Hosseini SA. Quality of life in mothers of children with cerebral palsy: The role of children's gross motor function. J Child Health Care 2014.

13. Prudente CO, Barbosa MA, Porto CC. Relation between quality of life of mothers of children with cerebral palsy and the children's motor functioning, after ten months of rehabilitation. Rev Lat Am Enfermagem 2010;18(2):14955 .

14. Düger T, Yilmaz $O$, Aki E, Kayihan $H$, Karaduman A. The environmental barriers of children with Muscular Dystrophies and its effect on mother's low back pain. Disabil Rehabil 2003;25(20):1187-92.

15. Chakour MC, Gibson SJ, Bradbeer M, Helme RD. The effect of age on A delta- and C-fibre thermal pain perception. Pain 1996;64(1):143,52.

16. Yilmaz H, Erkin G, Nalbant L. Depression and anxiety levels in mothers of children with cerebral palsy: a controlled study. Eur J Phys Rehabil Med 2013;49(6):823-7.

17. Tekinarslan IC. A comparison study of depression and quality of life in Turkish mothers of children with Down syndrome, cerebral palsy, and autism spectrum disorder. Psychol Rep 2013;112(1):266-87.

18. Mörelius $E$, Hemmingsson $H$. Parents of children with physical disabilities - perceived health in parents related to the child's sleep problems and need for attention at night. Child Care Health Dev 2014;40(3):412-8.

19. Herbert TB, Cohen S. Depression and immunity: a metaanalytic review. Psychol Bull 1993;113(3):472-86.

20. Taylor SE, Repetti RL, Seeman T. Health psychology: what is an unhealthy environment and how does it get under the skin? Annu Rev Psychol 1997;48:411-47.

21. Epel ES, Blackburn EH, Lin J, Dhabhar FS, Adler NE, Morrow $J D$, et al. Accelerated telomere shortening in response to life stress. Proc Natl Acad Sci U S A 2004;101(49):17312,5.

22. Tunks ER, Crook J, Weir R. Epidemiology of chronic pain with psychological comorbidity: prevalence, risk, course, and prognosis. Can J Psychiatry 2008;53(4):224-34. 